\title{
Attenuation by leptin of the effects of fasting on ovarian function in hens (Gallus domesticus)
}

\author{
H. E. Paczoska-Eliasiewicz ${ }^{1}$, A. Gertler ${ }^{2}$, M. Proszkowiec ${ }^{1}$, J. Proudman ${ }^{3}$,

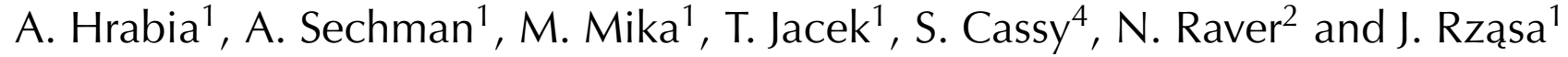 \\ ${ }^{1}$ Department of Animal Physiology, University of Agriculture, Kraków, Poland; ${ }^{2}$ Institute of Biochemistry, \\ Food Science and Nutrition, The Hebrew University of Jerusalem, Rehovot, Israel; ${ }^{3}$ Biotechnology and \\ Germplasm Laboratory, USDA-ARS, Beltsville, Maryland, USA; and ${ }^{4}$ Station de Recherches Avicoles,
} INRA, Nouzilly, France

Thirty-four-week-old laying hens received injections of recombinant chicken leptin to assess the role of leptin in avian ovarian function. In the first experiment, the hens $(n=60)$ were divided into three groups: (i) fed ad libitum; (ii) fasted; and (iii) fasted + leptin. Hens were fasted for 5 days and those treated with leptin received $250 \mu \mathrm{g}$ leptin $\mathrm{kg}^{-1}$ body weight twice a day, i.p. In the second experiment, the hens $(n=72)$ were divided into four groups: (i) fed ad libitum; (ii) fasted; (iii) fasted + leptin given only during fasting ( 5 days); or (iv) fasted and leptin given during both fasting and 5 days of re-feeding (10 days). LH was measured in blood plasma, and progesterone and oestradiol were measured in blood plasma and the ovary by radioimmunoassay. Apoptosis was examined in the walls of the three largest yellow hierarchical follicles (F3-F1; F3 < F2 < F1; 25-35 mm) by the TdT-mediated dUTP nick-end labelling method. Results showed that the injections of leptin during fasting: (i) delayed cessation of egg laying; (ii) attenuated regression of yellow hierarchical follicles; (iii) altered ovarian steroidogenesis; and (iv) abolished the fasting-induced apoptosis in the wall of F3-F1 follicles during the first $\mathbf{2}$ days of fasting and partially attenuated apoptosis after 5 days of fasting. Prolongation of leptin injections into the re-feeding period considerably delayed the restoration of the ovary. Expression of leptin receptor in laying hens was determined by RT-PCR. The highest expression of leptin receptor was observed in the hypothalamus. Lower receptor mRNA expression was found in the hypophysis, whereas the lowest expression was observed in the ovary. Within the ovary, a relatively high expression of leptin receptor was found in the stroma with cortical follicles $<1 \mathrm{~mm}$, the wall of white (1-8 mm) and small yellow follicles (> 8-12 mm), and the granulosa layer of $F 3$ follicles. The expression of leptin receptor in the granulosa layer of F2 and F1 follicles was barely detectable. This was in contrast to a much higher expression of leptin receptor maintained in the theca layer of F3-F1 follicles. The present results indicate that in chickens leptin might be involved in the adaptation to starvation due to attenuation of follicular apoptosis. The presence of leptin receptors in the ovary indicates the possibility of a peripheral effect of the hormone.

\section{Introduction}

In the laying chicken ovary there are two different populations of follicles: (i) white, slow-growing follicles $(1-8 \mathrm{~mm})$ that are highly susceptible to atresia; and (ii) yellow, rapidly growing follicles (> 8-36 mm), arranged in a size hierarchy, that are committed to ovulation and under normal physiological conditons are resistant to becoming atretic (for review, see Johnson, 1996, 2002). The regression of yellow hierarchical follicles occurs at the end of the reproductive season and is followed by cessation of egg laying and moulting that improves egg production because birds undergo a reproductive rejuvenation (Heryanto et al., 1997a,b;

Email: rzeliasi@cyf-kr.edu.pl
Yoshimura et al., 1997; Chowdhury and Yoshimura, 2002). Artificially induced moulting has been developed in poultry husbandry as a management tool for extending flock performance. The most widely practised method to induce a moult is fasting (for review, see Wolford, 1984; Brake, 1993), although this procedure is not permitted in many countries. Previous studies showed that circulating concentrations of $\mathrm{LH}$, progesterone and oestradiol decrease during fasting leading to the regression of the ovary and cessation of egg laying (Tanabe et al., 1981; Etches et al., 1984; Hoshino et al., 1988; Proszkowiec and Rząsa, 2001).

Leptin, an adipose tissue-derived hormone, acts in mammals as a metabolic signal between peripheral lipid stores and the central nervous system and plays an important role in the regulation of food intake, energy 
expenditure and reproduction (for review, see Friedman and Halaas, 1998; Houseknecht et al., 1998; Clarke and Henry, 1999; Caprio et al., 2001; Moschos et al., 2002; Smith et al., 2002). It has been shown that exogenous leptin stimulates the reproductive system by rescuing the sterility of leptin-deficient $o b / o b$ mice (Chehab et al., 1996) and advancing the onset of puberty or at least reversing the delay caused by food restriction in normal mice (Ahima et al., 1997; Chehab et al., 1997; Cheung et al., 2001), rats (Cheung et al., 1997, 2001; Almog et al., 2001) and chickens (Paczoska-Eliasiewicz et al., $2003 a, b)$. It has also been found that leptin injections attenuate the neuroendocrine response to fasting (Ahima et al., 1996; Nagatani et al., 1998, 2000). Initially leptin was thought to serve mainly as an 'anti-obesity' hormone but more recent studies have shown that leptin might be a 'starvation' hormone and its predominant role might be to signal an energy deficit rather than an excess (for review, see Flier, 1988; Ahima and Flier, 2000; Prentice et al., 2002). Caprio et al. (2001) suggested that leptin has a dual effect on reproduction and that the major site of leptin action depends on its circulating concentration in the blood, which reflects changes in the energy balance. According to this hypothesis, at low concentrations leptin acts mainly at the central level. At high concentrations the central leptin receptors are protected from hyperleptinaemia by the saturable transport system of blood-brain barrier (for review, see Ingvartsen and Boisclair, 2001), whereas the peripheral receptors are exposed to high leptin concentrations that exert an inhibitory action on gonadal steroidogenesis (for review, see Caprio et al., 2001; Moschos et al., 2002) and ovulation (Duggal et al., 2000). Therefore, the positive action of leptin at the hypothalamo-pituitary axis might be crucial for normal reproduction and in conditions with abnormally low plasma leptin concentrations, whereas its negative effect at the gonads might occur during hyperleptinaemia.

Chicken leptin cDNA was cloned by Taouis et al. (1998) and its sequence was confirmed by Ashwell et al. (1999a). Turkey leptin cDNA has also been cloned and sequenced (GenBank AF 082501). Turkey leptin exhibits very high identity to the chicken leptin, and the similarity of the leptin of both birds with most of the mammalian leptins is more than $80 \%$ (Taouis et al., 2001). Recombinant chicken leptin based on this sequence was synthesized by Raver et al. (1998) and its biological activity was shown both in vitro and in vivo (Raver et al., 1998; Dridi et al., 2000a). The mature chicken protein shows minor differences from the mammalian forms, including the presence of only 145 amino acids and unpaired cysteine at position 3 (Taouis et al., 1998; Dridi et al., 2000a). Unlike mammalian leptin, chicken leptin is expressed both in adipose and hepatic tissues (Taouis et al., 1998; Ashwell et al., 1999a,b; Richards et al., 2000) and the liver is apparently the major source (Ashwell et al., 1999a).
Leptin is most likely associated with the primary role of liver in avian lipogenesis (Saadoun and Leclercq, 1983). The decrease in food intake observed in layer and broiler chickens injected with recombinant chicken, ovine or human leptin indicates that in birds leptin plays a similar role in regulating the energy balance as it does in mammals (Denbow et al., 2000; Dridi et al., 2000a), although one study reported that intracerebroventricular administration of mouse leptin had no effect on food intake in chickens (Bungo et al., 1999). Furthermore, the plasma leptin concentration is under nutritional control such that lower leptin concentrations occur in the fasted state than in the fed state (Dridi et al., 2000b). Cloning of the chicken leptin receptor (Horev et al., 2000; Ohkubo et al., 2000) and detection of its presence in the hypothalamus (Horev et al., 2000) and the ovary (Ohkubo et al., 2000) indicate that leptin might be involved in the regulation of the chicken reproductive system although this possible function has not yet been explored. The present study was devoted to examining the effect of recombinant chicken leptin on events occurring in the chicken ovary during fasting.

Whether this protein is the native chicken leptin (Taouis et al., 1998; Ashwell et al., 1999a; Doyon et al., 2001) or is a mammalian-derived leptin analogue as suggested by others (Friedman-Einat et al., 1999; Pitel et al., 2000; Dunn et al., 2001) is controversial; however, the recombinant protein produced in the present authors' laboratory exhibited leptin-like activities both in vitro and in vivo. Those activities included: (i) activation of the long form of leptin receptor in Baf/3 cells stably-transfected with the long form of human leptin receptor (Raver et al., 1998); (ii) attenuation of food intake in layer and broiler chickens (Dridi et al., 2000a); (iii) recognition of antibodies raised against ovine leptin (Raver et al., 2000); (iv) interaction with human and chicken leptinbinding domain subcloned from the respective leptin receptors (Raver et al., 2003); and finally (v) ability to advance sexual maturation in female chickens (PaczoskaEliasiewicz et al., 2003a,b). All these activities were probably transduced through leptin receptors.

\section{Materials and Methods}

\section{Reagents}

Recombinant chicken leptin was prepared using prokaryotic expression vector pMON3401 encoding full size A (-1) chicken leptin (Raver et al., 1998). Spectria progesterone $\left[{ }^{125} \mathrm{I}\right]$ and oestradiol $\left[{ }^{125} \mathrm{I}\right]$ kits were purchased from Orion Diagnostica (Espoo) and in situ cell death detection kit (POD) from Roche Diagnostic (Mannheim). Purified chicken LH and antiserum against chicken LH were from USDA-ARS (Beltsville, MD). The chemicals for RT-PCR were purchased from the following companies: RNA Insta Pure (Eurogentec, Angers), Ambion's DNA-free kit (Clinisciences, Montrouge), 
Superscript II RNAse $\mathrm{H}^{-}$Reverse Transcriptase, Superscript II (Invitrogen, Cergy Pontoise), random hexamer primers (Promega, Charbonnieres), dNTP mix (Sigma, St Louis, MO) and Taq DNA Polymerase (Amersham Biosciences, Orsay). All other chemicals were purchased from ICN Biomedicals (Aurora, IL).

\section{Animals and experimental design}

All animal experiments were conducted according to the research protocols approved by the State Committee for Scientific Research in Warsaw, Poland. Hy-Line Brown laying hens at 30 weeks of age were purchased in September 2001 and 2002 for Expts 1 and 2, respectively, from the commercial farm Drobeco, Bielsko Biala, Poland. Birds were kept in individual cages and provided with commercial food and water ad libitum, under a photoperiod of $14 \mathrm{~h}$ light: $10 \mathrm{~h}$ dark with lights on at $07.00 \mathrm{~h}$. Oviposition time was recorded daily between $07.00 \mathrm{~h}$ and $15.00 \mathrm{~h}$ at $30 \mathrm{~min}$ intervals. Ovulation was considered to occur within 45 min after oviposition of the previous egg in the series on the basis of the oviposition time and cloacal palpation. After 4 weeks of acclimation, chickens laying 10 eggs or more in a clutch were chosen for experiments. In both experiments hens were fasted from days 1 to 5 and then fed ad libitum. Recombinant chicken leptin dissolved in PBS-BSA (10 $\mathrm{mg} \mathrm{ml}^{-1}$ ) was injected (i.p.) twice a day $(07.30 \mathrm{~h}$ and $19.30 \mathrm{~h})$ at a dose of $250 \mu \mathrm{g}(0.25 \mathrm{ml})^{-1}$ PBS-BSA kg-1 body weight, from days 1 to $5(\mathrm{~L} 1-5)$ or from days 1 to 10 (L1-10) of the experiment. Control hens and hens fasted and not given leptin injections received PBS-BSA. The dose of leptin was chosen according to clearance experiment performed in $30 \mathrm{~kg}$ ewes in which application of $2.5 \mathrm{mg}$ of ovine leptin resulted in half-life of about 50-60 min, yielding a leptin blood concentration of 55-90 $\mathrm{ng} \mathrm{ml}^{-1}$ at zero time and falling exponentially to $10 \mathrm{ng} \mathrm{ml}^{-1}$ within 5-7 h (D. H. Keisler, personal communication). Body weight, food intake and egg production were recorded daily. Blood was taken from the wing vein to heparinized tubes $20 \mathrm{~h}$ before predicted ovulation in laying hens and in non-laying hens between $14.00 \mathrm{~h}$ and $16.00 \mathrm{~h}$. Plasma was collected after centrifugation $(7 \mathrm{~min}, 1000 \mathrm{~g}$ ) and kept at $-20^{\circ} \mathrm{C}$ until $\mathrm{LH}$, progesterone and oestradiol determinations. The hypothalamus, the hypophysis or ovarian tissues were isolated, frozen in liquid nitrogen and kept at $-80^{\circ} \mathrm{C}$ until RNA isolation or progesterone and oestradiol assays.

Experiment 1. Hens $(n=60)$ were divided into three groups: (i) fed ad libitum (control; $n=12$ ); (ii) fasted (F; $n=24)$; and (iii) fasted + leptin given for 5 days ( $F+$ L1-5; $n=24)$. Plasma LH, progesterone and oestradiol concentrations were determined on days $0,3,6$ and on the day on which egg laying resumed after refeeding, that is between days 14 and 17 of the experi- ment. In both experimental groups six hens were killed on days 3 and 6 , and 12 hens were killed on the day that egg laying resumed. Control hens were killed on day 17 . The ovaries were removed immediately after decapitation, weighed, placed on ice and the following ovarian compartments were isolated: stroma with follicles $<1 \mathrm{~mm}$, white non-hierarchical follicles $(1-8 \mathrm{~mm})$, yellow hierarchical follicles (Fn-F1; > 8-35 mm) and postovulatory follicles (P1-Pn). Atretic follicles in the population of white follicles were identified macroscopically by their deformed or shrunken appearance (Gilbert et al., 1985), whereas normal follicles were divided into four classes: $1-2,>2-4,>4-6$ and $>6-8 \mathrm{~mm}$. In a similar way, atretic follicles in the population of yellow hierarchical follicles were recognized macroscopically. The weight of ovarian stroma and the number and weight of all follicles in the given population and class of follicles was recorded. Paraffin wax tissue sections of the wall of the three largest yellow hierarchical follicles (F3-F1; F3 < F2 < F1; 25-35 mm) were examined for histological and apoptotic changes on days 3 and 6 of the experiment.

Experiment 2. Hens $(n=72)$ were divided into four groups: (i) fed ad libitum (control; $n=12$ ); (ii) fasted (F; $n=24)$; (iii) fasted + leptin given for 5 days $(\mathrm{F}+\mathrm{L} 1-5$; $n=24)$; and (iv) fasted + leptin given for 10 days ( $\mathrm{F}+$ L1-10; $n=12$ ). Plasma LH, progesterone and oestradiol concentrations were measured on days $0,3,6$ and 11 . In control and $\mathrm{F}+\mathrm{L} 1-10$ groups ovaries were isolated on day $11(n=12)$, whereas the ovaries were isolated in the $\mathrm{F}$ and $\mathrm{F}+\mathrm{L} 1-5$ groups on days $3(n=6), 6(n=6)$ and $11(n=12)$ and characterized as described in Expt 1. Ovarian steroid hormones were measured on days 3, 6 and 11 ( $n=6$ for each group). Ovarian progesterone concentrations were measured in the wall of yellow hierarchical and postovulatory follicles, whereas ovarian oestradiol concentrations were measured in the stroma (including follicles $<1 \mathrm{~mm}$ ) and in the walls of all populations of ovarian follicles. The total contents of these steroids per ovary was calculated. Additionally, the hypothalamus, the hypophysis and the ovary of control laying hens, killed $20 \mathrm{~h}$ before predicted ovulation, were used for RT-PCR analysis of leptin receptors. In the case of the ovary the following compartments were examined: (i) stroma with follicles $<1 \mathrm{~mm}$; (ii) the wall of white (1-2, $>2-4,>4-6$ and $>6-8 \mathrm{~mm}$ ) and small yellow (>8$12 \mathrm{~mm}$ ) follicles; and (iii) the granulosa and the theca layer of the three largest yellow F3-F1 follicles separated according to Gilbert et al. (1977).

\section{Hormonal assays}

Plasma LH concentrations were determined using a homologous chicken $\mathrm{LH}$ radioimmunoassay. Purified chicken LH (Krishnan et al., 1994), LH antiserum and secondary antibody were provided by the USDA Animal 
Hormone Program, and the assay was performed according to recommendations supplied with the reagents. The lowest detectable concentration of LH was $100 \mathrm{pg} \mathrm{ml}^{-1}$ and the intra- and interassay coefficients of variation were $3.1 \%$ and $6.2 \%$, respectively. Progesterone and oestradiol concentrations in blood plasma and ovarian tissues were measured radioimmunologically using Spectria kits (Orion Diagnostica). The detection limit for progesterone was $90 \mathrm{pg} \mathrm{ml}^{-1}$ and for oestradiol it was $5.45 \mathrm{pg} \mathrm{ml}^{-1}$. The intra- and interassay coefficients of variation for progesterone and oestradiol were $4.4 \%$, $5.1 \%$ and $5.9 \%, 6.2 \%$, respectively.

\section{Histology and apoptosis evaluation}

The three largest yellow hierarchical F1-F3 follicles were fixed in $4 \%(\mathrm{v} / \mathrm{v})$ buffered paraformaldehyde, routinely processed and embedded in paraffin wax. Sections $(6 \mu \mathrm{m})$ were stained with haematoxylin and eosin and examined histologically using a Nicon-300 light microscope (Tokyo). For evaluation of apoptosis, deparaffinized sections were incubated with proteinase $\mathrm{K}\left(20 \mu \mathrm{g} \mathrm{ml}^{-1}\right)$ in $10 \mathrm{mmol}$ Tris- $\mathrm{HCl} \mathrm{I}{ }^{-1}\left(\mathrm{pH} 7.4,37^{\circ} \mathrm{C}\right.$, $20 \mathrm{~min}$ ) and apoptotic cells were detected by the TdTmediated dUTP nick-end labelling (TUNEL) method (Gavrieli et al., 1992) using the in situ cell death detection kit (POD) according to manufacturer's instruction. Negative controls of the examined sections were incubated without terminal deoxynucleotidyl transferase. Sections were incubated with $\mathrm{DAB}-\mathrm{H}_{2} \mathrm{O}_{2}$ mixture to visualize the immunoreaction products. TUNEL-positive cells were counted on 10 random areas $(50 \times 50 \mu \mathrm{m})$ of each examined follicular wall under Nicon-300 light microscope.

\section{$R T-P C R$ analysis}

Total RNA was isolated from the specified tissues using RNA Insta Pure according to the manufacturer's recommendations. After DNAse treatment using Ambion's DNA-free kit, $2 \mu \mathrm{g}$ of total RNAs were reverse transcribed using RNAse $\mathrm{H}^{-}$MMLV reverse transriptase and random hexamer primers. RT products $(2 \mu \mathrm{l})$ were amplified for 30 cycles in a $50 \mu \mathrm{l}$ reaction volume containing 2.5 units of Taq DNA polymerase, $0.2 \mu \mathrm{mol} \mathrm{I^{-1 }}$ of each forward and reverse primer, $2.5 \mathrm{mmol} \mathrm{MgCl}_{2} \mathrm{I}^{-1}$ and $0.2 \mathrm{mmol}$ dNTPs $\left.\right|^{-1}$. The amplification conditions were as follows: denaturation at $94^{\circ} \mathrm{C}$ for $30 \mathrm{~s}$, annealing at $60^{\circ} \mathrm{C}$ for $30 \mathrm{~s}$ and primer extension at $72^{\circ} \mathrm{C}$ for $30 \mathrm{~s}$. After final extension at $72^{\circ} \mathrm{C}$ for $7 \mathrm{~min}, \mathrm{PCR}$ products were resolved on $1.5 \%$ agarose gel containing ethidium bromide. PCR amplification of cDNA samples was carried out using the following primer pairs: rec 1 forward $\left(5^{\prime}\right.$-GTC CAC GAG ATT CAT CCC AG-3') and rec1 reverse (5'-CCT GAG ATG CAG AGA TGC TC-3') for amplification of a $271 \mathrm{bp}$ fragment of the leptin receptor cDNA located in the coding sequence of the extra-cellular domain; rec2 forward (5'-GCT TGC TCA GGT AGC TCC TG-3') and rec2 reverse (5'-TGC GGC ACG TAT GGC ACG AT-3') for amplification of a $359 \mathrm{bp}$ fragment of the leptin receptor cDNA located in the coding sequence of the cytoplasmic domain; and 18S forward (3'-CGC GTG CAT TTA TCA GAC CA-3') and $18 \mathrm{~S}$ reverse (5'-ACC CGT GGT CAC CAT GGT A-3') for the amplification of a 148 bp fragment of $18 \mathrm{~S}$ ribosomal RNA (internal control). The primers were selected according to the published chicken cDNA sequences of leptin receptor (Horev et al., 2000; Ohkubo et al., 2000) and $18 \mathrm{~S}$ ribosomal RNA (van Tuinen et al., 2000).

\section{Statistical analysis}

Data were analysed by different statistical analyses that are specified in the legend of each table or figure. The tests included one-, two- or three-way ANOVA followed by either $t$ test for comparison of two means or Tukey's Studentized Range (HSD) test for comparison of multiple means. Data of the effect of leptin on cessation and resumption of egg laying were calculated using non-parametric Wilcoxon two-sample (two-sided) test. Results are expressed as means \pm SEM and considered significantly different at $P<0.05$. In most cases in which the $F$ values for interaction (experiment $\times$ treatment and experiment $x$ day) were not significant the data for Expts 1 and 2 were pooled.

\section{Results}

\section{Body weight (Expts 1 and 2)}

Initial body weight did not differ significantly among experimental groups or between experiments (overall mean $1882 \pm 46 \mathrm{~g}$ ). The mean body weight of control hens ranged from $1883 \pm 47 \mathrm{~g}$ to $2009 \pm 50 \mathrm{~g}$ during the experiments. Five days of fasting resulted in a decline in body weight that was similar in all fasted groups (77.5\%, $79.6 \%$ and $79.1 \%$ of initial body weight for $F$, $\mathrm{F}+\mathrm{L} 1-5$ and $\mathrm{F}+\mathrm{L} 1-10$, respectively; $P>0.05$ ), whereas body weight recovered similarly in these groups after 5 days of re-feeding $(93.5 \%, 94.9 \%$ and $90.9 \%$ of initial body weights, respectively; $P>0.05)$. At resumption of egg laying, that is between 9 and 12 days of re-feeding, the body weights of $\mathrm{F}$ and $\mathrm{F}+\mathrm{L} 1-5$ hens were $104.9 \%$ and $105.5 \%$ of their initial body weights, respectively $(P>0.05)$.

\section{Food intake (Expts 1 and 2)}

The results were first analysed by two-way ANOVA (experiment $x$ day and experiment $x$ treatment). As the $F$ values for both interactions were not significant $(P<0.38)$ the results of both experiments were pooled and re-analysed by one-way ANOVA followed by HSD test. Fasted hens injected with leptin consumed less feed 
Table 1. Effect of leptin on cessation and resumption of egg laying in fasted and re-fed hens

\begin{tabular}{llccc}
\hline & & \multicolumn{2}{c}{ Number of days to stop or re-start laying } \\
\cline { 3 - 5 } Expt & Treatment $^{\mathrm{a}}$ & Number of hens & Mean \pm SEM $^{\mathrm{b}}$ & Median \\
\hline \multirow{3}{*}{1} & & \multicolumn{3}{c}{ Cessation } \\
& Fasted & 18 & $2.2 \pm 0.16$ & 2.0 \\
& Fasted + leptin & 18 & $3.1 \pm 0.14^{* *}$ & 3.0 \\
2 & Fasted & 30 & $2.5 \pm 0.13$ & 2.0 \\
& Fasted + leptin & 30 & $3.1 \pm 0.15^{*}$ & 3.0 \\
& & & Resumption & \\
1 & Fasted & 12 & $12.3 \pm 0.23$ & 12.0 \\
& Fasted + leptin & 12 & $10.3 \pm 0.20^{*}$ & 10.0 \\
\hline
\end{tabular}

a In control, fed ad libitum hens ( $n=12$ for each experiment) egg-laying rate ranged from $91.7 \%$ to $100 \%$. Hens were fasted from days 1 to 5 and then fed ad libitum (fasted) or were fasted from days 1 to 5 and injected with recombinant chicken leptin $\left(250 \mu \mathrm{g} \mathrm{kg}^{-1}\right.$ body weight, i.p., twice a day) during fasting and then fed ad libitum (fasted + leptin).

${ }^{b}$ The differences between fasted and fasted+leptin groups were analysed by Wilcoxon two-sided non-parametric test; ${ }^{* *} P<0.002$ and ${ }^{*} P<0.01$ in comparison with fasted group.

${ }^{\mathrm{C}}$ Calculated from the day of cessation of egg laying.

during the 5 days after the fasting, that is from days 6 to 10, than did control hens $(P<0.05)$. Average daily feed intake for this period (mean \pm SEM) was $133.1 \pm 2.2 \mathrm{~g}$ per day for controls and $126.2 \pm 3.2 \mathrm{~g}$ per day for $\mathrm{F}$ hens, whereas leptin-treated hens consumed $120.7 \pm 3.2 \mathrm{~g}$ per day $(\mathrm{F}+\mathrm{L} 1-5)$ and $109.3 \pm 3.9 \mathrm{~g}$ per day $(\mathrm{F}+\mathrm{L} 1-10)$. Feed consumption by the $F$ hens was not significantly different from that of controls, but was significantly higher than that of the $\mathrm{F}+\mathrm{L} 1-10$ group $(P<0.05)$. The two leptin-treated groups did not differ significantly in feed consumption from days 6 to 10, nor did feed consumption differ significantly among control, $\mathrm{F}$ and $\mathrm{F}+\mathrm{L} 1-5$ hens from day 11 until resumption of egg laying $(133.7 \pm 2.9,141.4 \pm 3.4$ and $139.7 \pm 3.8 \mathrm{~g}$ per day, respectively).

\section{Egg-laying rate (Expts 1 and 2)}

Leptin given during fasting significantly $(P<0.002$ and $P<0.01$ for Expt 1 and Expt 2, respectively) delayed the cessation of egg laying but all fasted hens stopped laying by day 5 (Table 1). Leptin given during fasting also significantly $(P<0.01)$ accelerated the rate at which hens resumed egg laying after re-feeding in comparison with re-fed hens not treated with leptin during fasting.

\section{Morphological characteristics of the ovary (Expts 1 and 2)}

Treatment with leptin for 5 days during fasting significantly attenuated the rate of regression of the ovary (Table 2 ). Control, $\mathrm{F}$ and $\mathrm{F}+\mathrm{L} 1-5$ groups did not differ in ovary mass after completing 2 days of fasting (day 3 ), but after 5 days (day 6 ) the $F$ hens showed a significant $(P<0.05)$ reduction in ovary mass compared with controls. Leptin attenuated the effect of fasting and the $\mathrm{F}+\mathrm{L} 1-5$ hens had larger ovaries after 5 days of fasting than did $\mathrm{F}$ hens; the difference was on the border of significance in Expt $1(P<0.06)$ and significant $(P<0.05)$ in Expt 2. After 5 days of re-feeding (day 11 ), the ovary mass of $\mathrm{F}$ and $\mathrm{F}+\mathrm{L} 1-5$ groups were not different but still significantly lower than in the non-fasted controls, whereas the ovary mass of the hens injected with leptin during fasting and re-feeding $(F+L 1-10)$ was significantly lower than those of the $F$ and $F+L 1-5$ groups. At resumption of egg laying the ovary mass of $\mathrm{F}$ and $\mathrm{F}+\mathrm{L} 1-5$ hens did not differ from that of controls.

The number and weight of yellow hierarchical follicles (Table 3) as well as their appearance did not differ among control, $\mathrm{F}$ and $\mathrm{F}+\mathrm{L} 1-5$ hens after 2 days of fasting (day 3), but during the next 3 days of fasting the number and weight of normal follicles in $\mathrm{F}$ and $\mathrm{F}+\mathrm{L} 1-$ 5 hens declined significantly $(P<0.05)$ in comparison with controls, and on day 6 atretic follicles were found in the ovaries of both fasted groups (Table 3). However, in $\mathrm{F}$ hens all large yellow follicles were shrunken, haemmorhagic and grossly regressed, whereas such follicles still contained yellow yolk in $\mathrm{F}+\mathrm{L} 1-5$ hens, although some loss of surface turgidity of the follicles was evident; the weight of atretic follicles was significantly $(P<0.05)$ greater in the $\mathrm{F}+\mathrm{L} 1-5$ hens than in the $\mathrm{F}$ hens (Table 3). After 5 days of re-feeding (day 11), the number of normal follicles in $\mathrm{F}$ and $\mathrm{F}+\mathrm{L} 1-5$ hens did not differ significantly from controls, but follicle mass was significantly $(P<0.05)$ lower in both fasted groups. The number and mass of atretic follicles did not differ between $\mathrm{F}$ and $\mathrm{F}+\mathrm{L} 1-5$ hens. Hens in the $\mathrm{F}+\mathrm{L} 1-10$ group had significantly $(P<0.05)$ fewer normal follicles and fewer atretic follicles than any other fasted group after 5 days of re-feeding. At resumption of egg laying, the ovaries of $\mathrm{F}$ and $\mathrm{F}+\mathrm{L} 1-5$ hens contained only normal follicles and their number and mass were not different from those of control hens (Table 3). The weights of the ovarian stroma (including follicles $<1 \mathrm{~mm}$ ) as well as the masses of white follicles in each class of size (1-2, $>2-4,>4-6$ and $>6-8$ ) and the numbers of follicles in these classes did not differ significantly among treatment groups at any time point examined (data not shown), except the class $>6-8 \mathrm{~mm}$ follicles. The masses of these follicles (mean \pm SEM) were significantly $(P<0.05)$ lower in $\mathrm{F}(0.72 \pm 0.11 \mathrm{~g})$ and $\mathrm{F}+\mathrm{L} 1-5(0.85 \pm 0.10 \mathrm{~g})$ hens after 5 days of fasting than in controls $(1.4 \pm 0.09 \mathrm{~g})$.

\section{Histology and apoptosis of yellow hierarchical follicles}

The histological structure of the F1 follicle of (a) control, (b) $\mathrm{F}$ and (c) $\mathrm{F}+\mathrm{L} 1-5$ hens after 3 days of fasting (day 3 ) is shown in Fig. 1. The walls of the three largest yellow follicles (F1-F3) of F hens showed atretic 
Table 2. Effect of leptin on the ovary mass (g) in fasted and re-fed hens (Expts I and 2)

\begin{tabular}{|c|c|c|c|}
\hline \multirow[b]{2}{*}{ Day } & \multirow[b]{2}{*}{ Treatment* } & \multicolumn{2}{|c|}{$\begin{array}{l}\text { Ovary mass (mean } \pm \text { SEM })^{\dagger} \\
\quad \text { (number of hens) }\end{array}$} \\
\hline & & Expt 1 & Expt 2 \\
\hline & Control, fed ad libitum & $45.7 \pm 2.95^{\mathrm{a}}(12)$ & $47.0 \pm 2.05^{\mathrm{a}}$ \\
\hline 3 & $\begin{array}{l}\mathrm{F} \\
\mathrm{F}+\mathrm{L} 1-5\end{array}$ & $\begin{array}{l}42.7 \pm 6.88^{\mathrm{a}}(6) \\
45.0 \pm 9.24^{\mathrm{a}}(6)\end{array}$ & $\begin{array}{l}41.7 \pm 7.72^{\mathrm{a}}(6) \\
46.2 \pm 8.61^{\mathrm{a}}(6)\end{array}$ \\
\hline 6 & $\begin{array}{l}\mathrm{F} \\
\mathrm{F}+\mathrm{L} 1-5\end{array}$ & $\begin{array}{l}15.9 \pm 3.08^{b}(6) \\
28.0 \pm 4.15^{b}(6)\end{array}$ & $\begin{array}{l}14.2 \pm 2.24^{\mathrm{c}, \mathrm{d}}(6) \\
26.5 \pm 4.03^{\mathrm{b}}(6)\end{array}$ \\
\hline 11 & $\begin{array}{l}F \\
F+L 1-5 \\
F+L 1-10\end{array}$ & $\begin{array}{l}\text { NT } \\
\text { NT } \\
\text { NT }\end{array}$ & $\begin{aligned} 22.6 & \pm 3.83^{\mathrm{b}, \mathrm{c}}(12) \\
28.7 & \pm 4.07^{\mathrm{b}}(12) \\
7.4 & \pm 1.12^{\mathrm{d}}(12)\end{aligned}$ \\
\hline $14-17^{\ddagger}$ & $\begin{array}{l}F \\
F+L 1-5\end{array}$ & $\begin{array}{l}49.1 \pm 3.01^{\mathrm{a}}(12) \\
47.5 \pm 4.28^{\mathrm{a}}(12)\end{array}$ & $\begin{array}{l}\text { NT } \\
\text { NT }\end{array}$ \\
\hline
\end{tabular}

*All hens except the control were fasted from days 1 to 5 and then fed ad libitum; $\mathrm{F}+\mathrm{L} 1-5$ hens received leptin $\left(250 \mu \mathrm{g} \mathrm{kg}^{-1}\right.$ body weight, i.p., twice a day) for 5 days during fasting, whereas $\mathrm{F}+\mathrm{L} 1-10$ hens received leptin for 10 days during fasting and re-feeding (days 1-10); control and $\mathrm{F}$ hens received placebo (PBS-BSA).

TThe data of each experiment were analysed by one-way ANOVA (both $F$ values for effect of treatment at $P<0.0001$ ) followed by $t$ test using least significant difference values of 13.77 and 12.17 for Expts I and 2, respectively. Means marked with the same superscript letters in the same column do not differ significantly $(P<0.05)$.

${ }^{\ddagger}$ Resumption of egg laying. NT: not tested.

Table 3. Morphological characteristics of yellow hierarchical follicles in fasted and re-fed hens treated with leptin (Expts I and 2)

\begin{tabular}{|c|c|c|c|c|c|c|}
\hline \multirow[b]{2}{*}{ Day } & \multirow[b]{2}{*}{ Treatment* } & \multirow[b]{2}{*}{ Number of hens } & \multicolumn{2}{|c|}{$\begin{array}{l}\text { Number of follicles per ovary } \\
\qquad(\text { mean } \pm \text { SEM })\end{array}$} & \multicolumn{2}{|c|}{$\begin{array}{l}\text { Total weight of follicles }(g)^{\dagger} \\
\quad(\text { mean } \pm \text { SEM })\end{array}$} \\
\hline & & & Normal & Atretic & Normal & Atretic \\
\hline & Control, fed ad libitum & 24 & $7.1 \pm 0.31^{\mathrm{a}}$ & None & $40.1 \pm 2.42^{\mathrm{a}}$ & None \\
\hline 3 & $\begin{array}{l}\mathrm{F} \\
\mathrm{F}+\mathrm{L} 1-5\end{array}$ & $\begin{array}{l}12 \\
12\end{array}$ & $\begin{array}{l}6.8 \pm 0.48^{\mathrm{a}} \\
6.7 \pm 0.51^{\mathrm{a}}\end{array}$ & $\begin{array}{l}\text { None } \\
\text { None }\end{array}$ & $\begin{array}{l}36.7 \pm 3.71^{\mathrm{a}} \\
39.4 \pm 4.82^{\mathrm{a}}\end{array}$ & $\begin{array}{l}\text { None } \\
\text { None }\end{array}$ \\
\hline 6 & $\begin{array}{l}\mathrm{F} \\
\mathrm{F}+\mathrm{L} 1-5\end{array}$ & $\begin{array}{l}12 \\
12\end{array}$ & $\begin{array}{l}1.2 \pm 0.15^{\mathrm{b}} \\
1.5 \pm 0.17^{\mathrm{b}}\end{array}$ & $\begin{array}{l}5.8 \pm 0.42^{\mathrm{a}} \\
5.7 \pm 0.33^{\mathrm{a}}\end{array}$ & $\begin{array}{l}0.5 \pm 0.08^{c} \\
0.7 \pm 0.14^{c}\end{array}$ & $\begin{array}{l}10.9 \pm 1.5^{b} \\
19.8 \pm 2.7^{\mathrm{a}}\end{array}$ \\
\hline 11 & $\begin{array}{l}F \\
F+L 1-5 \\
F+L 1-10\end{array}$ & $\begin{array}{l}12 \\
12 \\
12\end{array}$ & $\begin{array}{l}5.7 \pm 0.71^{\mathrm{a}} \\
6.6 \pm 0.82^{\mathrm{a}} \\
1.8 \pm 0.34^{\mathrm{b}}\end{array}$ & $\begin{array}{l}5.1 \pm 0.53^{\mathrm{a}} \\
5.6 \pm 0.48^{\mathrm{a}} \\
4.8 \pm 0.21^{\mathrm{a}}\end{array}$ & $\begin{array}{r}15.2 \pm 2.18^{b} \\
20.6 \pm 2.80^{b} \\
1.9 \pm 0.38^{c}\end{array}$ & $\begin{array}{l}2.9 \pm 0.5^{\mathrm{c}} \\
3.7 \pm 0.6^{\mathrm{c}} \\
1.3 \pm 0.1^{\mathrm{d}}\end{array}$ \\
\hline $14-17^{\dagger}$ & $\begin{array}{l}\mathrm{F} \\
\mathrm{F}+\mathrm{L} 1-5\end{array}$ & $\begin{array}{l}12 \\
12\end{array}$ & $\begin{array}{l}7.8 \pm 0.44^{\mathrm{a}} \\
7.2 \pm 0.38^{\mathrm{a}}\end{array}$ & $\begin{array}{l}\text { None } \\
\text { None }\end{array}$ & $\begin{array}{l}43.9 \pm 4.21^{\mathrm{a}} \\
41.4 \pm 4.10^{\mathrm{a}}\end{array}$ & $\begin{array}{l}\text { None } \\
\text { None }\end{array}$ \\
\hline
\end{tabular}

*All hens except the control were fasted from days 1 to 5 and then fed ad libitum; $\mathrm{F}+\mathrm{L} 1-5$ hens received leptin ( $250 \mu \mathrm{g} \mathrm{kg}^{-1}$ body weight, i.p., twice a day) for 5 days during fasting whereas $F+L 1-10$ hens received leptin for 10 days, during fasting and re-feeding (days 1-10); control and $F$ hens received placebo (PBS-BSA).

†The data from Expts 1 and 2 for days 3 and 6 were first analysed by two-way ANOVA (treatment $\times$ experiment and day $\times$ experiment). As the $F$ values for the interaction effects were not significant $(P<0.23$ and $P<0.18$, respectively) the results of both experiments were pooled and re-analysed by one-way ANOVA ( $F$ value for effect of treatment at $P<0.001$ ) followed by Tukey's Studentized Range (HSD) test. The results for day 11 are from Expt 2 and the results for days 14-17 are from Expt 1. Means marked with the same superscript letters in the same column do not differ significantly $(P<0.05)$.

changes, including hypertrophy of the connective tissue, occurrence of new blood vessels in the theca layer, and folding and separation of the granulosa layer from the basement membrane. Follicles from $\mathrm{F}+\mathrm{L} 1-5$ hens did not differ in histological appearance from those of control hens. In the $\mathrm{F}$ hens the width of the walls of $\mathrm{F} 1(283 \pm$ $32.2 \mu \mathrm{m}), \mathrm{F} 2(260 \pm 29.8 \mu \mathrm{m})$ and $\mathrm{F} 3(237 \pm 27.0 \mu \mathrm{m})$ follicles was significantly $(P<0.05)$ greater than that of controls $(64 \pm 5.2, \quad 57 \pm 6.1$ and $60 \pm 5.1 \mu \mathrm{m}$, respectively) or $\mathrm{F}+\mathrm{L} 1-5$ hens $(77 \pm 7.2,71 \pm 6.1$ and 

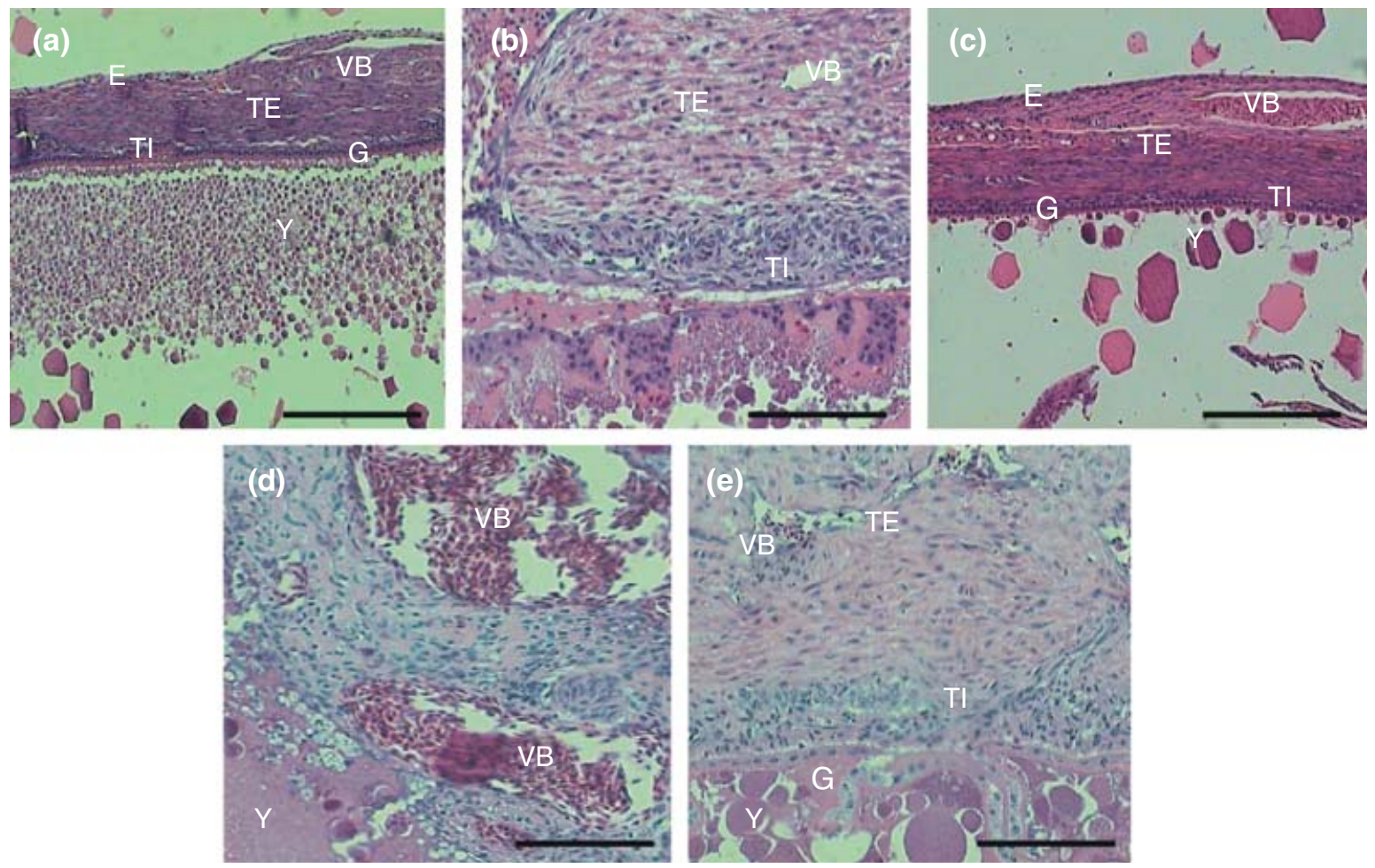

Fig. 1. The wall of the largest yellow hierarchical $F 1$ follicle in fasted (F) hens and hens treated with recombinant chicken leptin (250 $\mathrm{g} \mathrm{kg}^{-1}$ body weight, i.p., twice a day) during fasting $(\mathrm{F}+\mathrm{L} 1-5)$ stained with haematoxylin and eosin. (a) Hens fed ad libitum (control). (b) On day 3 in $\mathrm{F}$ hens the follicular wall showed atretic changes including hypertrophy of the connective tissue, occurrence of new blood vessels in the theca layer and in some places folding and separation of the granulosa layer from the basement membrane, whereas in (c) $\mathrm{F}+\mathrm{L} 1-5$ hens no signs of atresia were present. On day 6 atretic changes were seen in both (d) F and (e) F+L1-5 hens but in F hens discrimination of the follicular layers was not possible due to disappearance of the basement membrane and proliferation, and translocation of the theca and the granulosa cells towards the follicle lumen. (e) In F + L1-5 hens the wall still had layer arrangement and less newly formed blood vessels. E: epithelium with loose connective tissue; TE: theca externa; TI: theca interna; G: granulosa; VB: blood vessels; Y: yolk. Scale bars represent $100 \mu \mathrm{m}$.

$70 \pm 9.5 \mu \mathrm{m}$, respectively) after 2 days of fasting. After 5 days of fasting (day 6 ), atretic changes were observed in F1-F3 follicles of both F and F + L1-5 hens. The basement membrane could no longer be observed in the $\mathrm{F}$ hens, the follicle layers could not be discriminated, and many newly formed blood vessels were observed (Fig. 1d). The follicles of $\mathrm{F}+\mathrm{L} 1-5$ hens, in contrast, still had walls with apparent theca and granulosa layers and fewer blood vessels (Fig. 2e).

The number of apoptotic cells per unit area of follicle wall $(50 \mu \mathrm{m} \times 50 \mu \mathrm{m})$ is presented in Table 4. Relatively few TUNEL-positive apoptotic cells were observed in control hens, and these were located primarily in the epithelium and only occasionally in the granulosa and theca interna and externa layers. Fasted hens receiving leptin $(F+L 1-5)$ showed no changes in the number or location of apoptotic cells compared with controls after 2 days of fasting (day 3 ). In contrast, the hens fasted without leptin treatment $(\mathrm{F})$ showed a nearly twofold increase $(P<0.05)$ in the occurrence of apoptotic cells in F1-F3 follicles after 2 days of fasting (Table 4). Apoptotic cells were present in these hens in all layers of the examined follicles, but were found primarily in the granulosa and theca interna layers. After 5 days of fasting (day 6), apoptosis was apparent in $\mathrm{F}$ hens in the entire degenerated wall of F1-F3 follicles, whereas in the $\mathrm{F}+\mathrm{L} 1-10$ hens apoptosis was present primarily in the granulosa and theca interna layers of these follicles. Leptin treatment significantly attenuated the increase in the number of apoptotic cells caused by fasting. Follicles of $\mathrm{F}+\mathrm{L} 1-5$ hens had significantly $(P<0.05)$ fewer apoptotic cells after 5 days of fasting than did those of $\mathrm{F}$ hens, but apoptosis was significantly increased in both groups compared with controls (Table 4; $P<0.05$ ).

\section{Blood hormonal profiles (Expts 1 and 2)}

Fasting for 2 or 5 days significantly $(P<0.05)$ reduced the plasma concentrations of $\mathrm{LH}$, progesterone and oestradiol compared with controls (Table 5). Administration of leptin during fasting significantly $(P<0.05)$ : (i) attenuated the decrease in plasma $\mathrm{LH}$ during the 

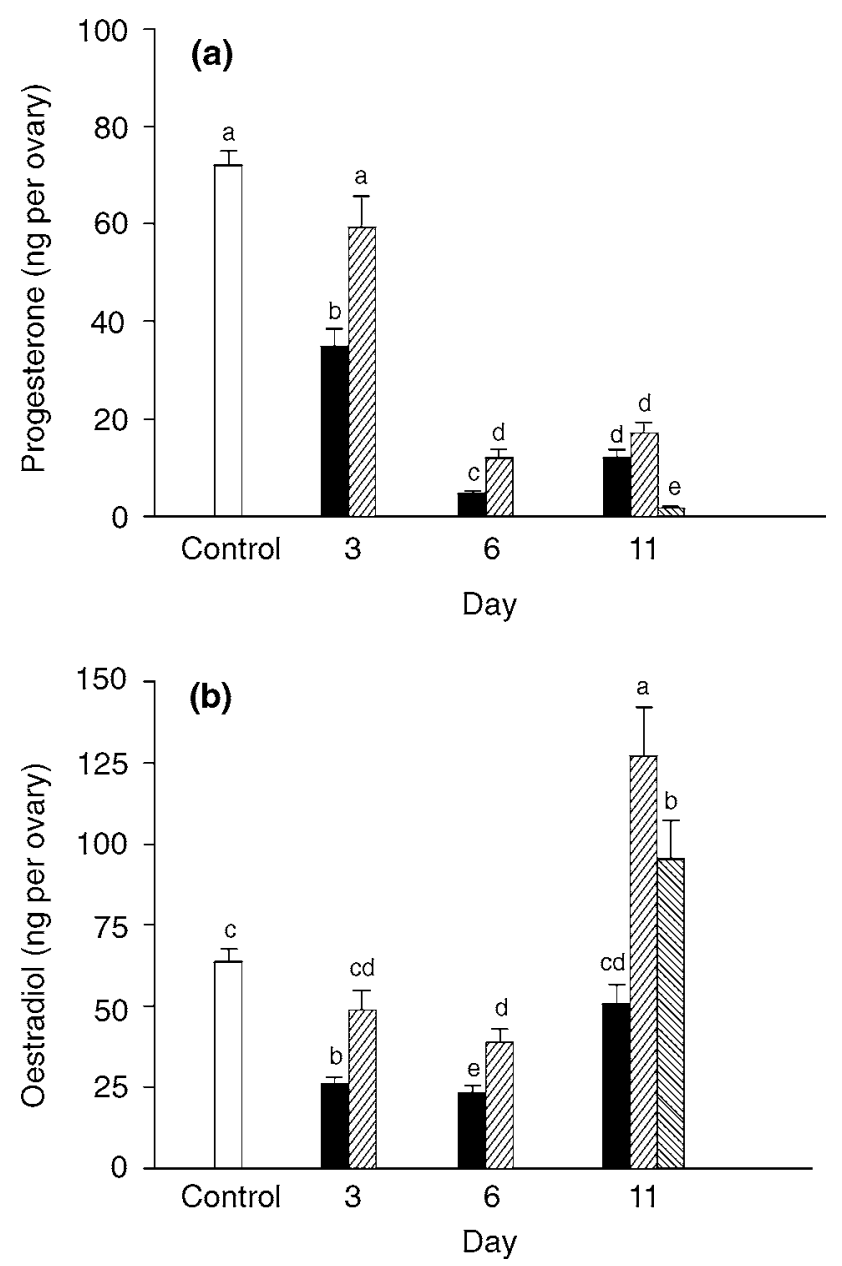

Fig. 2. Effect of leptin on ovarian (a) progesterone and (b) oestradiol content in fasted and re-fed hens. $\square$ : hens fed ad libitum (control); 口: hens fasted from days 1 to 5 and then fed ad libitum (F); and 圆: hens treated with recombinant chicken leptin $(250 \mu \mathrm{g} \mathrm{kg}$ body weight, i.p., twice a day) during fasting $(\mathrm{F}+\mathrm{L} 1-5)$ or $(\mathbb{\square}$ during fasting and re-feeding $(\mathrm{F}+\mathrm{L} 1-10)$. Each value represents the mean \pm SEM from six hens (Expt 2). Data were analysed by oneway ANOVA ( $F$ value for effect of treatment at $P<0.0002$ ) followed by Tukey's Studentized Range (HSD) test. Means marked with the same superscript letter do not differ significantly at $P<0.05$.

first 2 days of fasting; (ii) enhanced the decline of progesterone concentration observed after 5 days of fasting; and (iii) lessened the decline in plasma oestradiol concentrations during fasting. Hens that received leptin for either $5(\mathrm{~F}+\mathrm{L} 1-5)$ or 10 days $(\mathrm{F}+\mathrm{L} 1-10)$ had significantly $(P<0.05)$ higher plasma LH concentrations after 5 days of re-feeding (day 11) than did fasted and re-fed hens that had not received leptin (F). However, administration of leptin during re-feeding suppressed circulating gonadal steroid concentrations. Hens that received leptin during fasting and re-feeding $(\mathrm{F}+\mathrm{L} 1-10)$ had significantly $(P<0.05)$ lower plasma concentrations of both progesterone and oestradiol on day 11 in
Table 4. Effect of leptin on the number of apoptotic cells in the wall of the three largest yellow F1-F3 hierarchical follicles in fasted hens (Expt 1)

\begin{tabular}{lcrrr}
\hline & & \multicolumn{2}{c}{ Number of apoptotic cells ${ }^{\dagger}(\text { mean } \pm \text { SEM })^{\ddagger}$} \\
\cline { 3 - 5 } Day & Treatment* & Follicle F1 & Follicle F2 & Follicle F3 \\
\hline & $\begin{array}{c}\text { Control, fed } \\
\text { ad libitum }\end{array}$ & $10.2 \pm 0.43^{\mathrm{a}}$ & $9.5 \pm 0.51^{\mathrm{a}}$ & $9.9 \pm 0.42^{\mathrm{c}}$ \\
& & & \\
3 & $\mathrm{~F}$ & $18.3 \pm 1.59^{\mathrm{b}}$ & $17.7 \pm 1.42^{\mathrm{b}}$ & $19.4 \pm 1.71^{\mathrm{b}}$ \\
& $\mathrm{F}+\mathrm{L} 1-5$ & $9.1 \pm 0.95^{\mathrm{c}}$ & $8.8 \pm 0.72^{\mathrm{c}}$ & $10.1 \pm 0.87^{\mathrm{c}}$ \\
6 & F & $27.6 \pm 2.51^{\mathrm{a}}$ & $28.1 \pm 1.21^{\mathrm{a}}$ & $26.8 \pm 1.28^{\mathrm{a}}$ \\
& F + L1-5 & $18.8 \pm 0.77^{\mathrm{b}}$ & $20.4 \pm 1.77^{\mathrm{b}}$ & $18.0 \pm 1.71^{\mathrm{b}}$ \\
\hline
\end{tabular}

*Fasted from days 1 to 5 (F) and given leptin $\left(250 \mu \mathrm{g} \mathrm{kg}^{-1}\right.$ body weight, i.p., twice a day) during fasting $(\mathrm{F}+\mathrm{L} 1-5)$; control and $\mathrm{F}$ hens received placebo (PBS-BSA).

${ }^{\dagger}$ Apoptotic cells (TUNEL-positive) counted on 10 randomly chosen fields $(50 \mu \mathrm{m} \times 50 \mu \mathrm{m})$ of each follicular wall (F1, F2 or F3) were averaged for each hen for that microscopic field size and subsequently the average values from six hens were calculated as mean \pm SEM.

$¥$ The data were analysed by one-way ANOVA ( $F$ value for effect of treatment at $P<0.005$ ) followed by Tukey's Studentized Range (HSD) test. Means marked with the same superscript letters in the same column do not differ significantly $(P<0.05)$.

comparison with hens that had received leptin only during the period of feed withdrawal $(\mathrm{F}+\mathrm{L} 1-5)$. On the other hand, oestradiol concentration in the $\mathrm{F}+\mathrm{L} 1-5$ hens was significantly $(P<0.05)$ higher on day 11 as compared with other groups, including controls. At resumption of egg production (days 14-17), all plasma hormone concentrations measured were similar among treatment groups with the exception of a continuing increase of plasma oestradiol in the $\mathrm{F}+\mathrm{L} 1-5$ group $(P<0.05)$.

\section{Ovarian progesterone and oestradiol content (Expt 2)}

Changes in total progesterone and oestradiol content in the ovary of $\mathrm{F}, \mathrm{F}+\mathrm{L} 1-5$ and $\mathrm{F}+\mathrm{L} 1-10$ hens are presented in Fig. 2. The ovarian progesterone content in $\mathrm{F}$ hens was significantly $(P<0.05)$ lower than that of control hens on all tested days. Leptin given during fasting $(\mathrm{F}+\mathrm{L} 1-5)$ significantly $(P<0.05)$ attenuated the decrease on days 3 and $6(P<0.05)$ and had no effect on day 11 . The ovarian oestradiol content in $\mathrm{F}$ hens was significantly $(P<0.05)$ decreased in comparison with control hens on days 3 and 6 and did not differ on day 11 . In hens treated with leptin during fasting $(\mathrm{F}+\mathrm{L} 1-5)$, the ovarian oestradiol content on days 3,6 and 11 was significantly $(P<0.05)$ higher in comparison with that of $\mathrm{F}$ hens, although the most pronounced stimulatory effect of leptin occurred on day 11. Continuation of leptin injections into the re-feeding period ( $\mathrm{F}+\mathrm{L} 1-10$ hens) significantly $(P<0.05)$ decreased the ovarian progesterone content on day 11 in comparison with that of $\mathrm{F}$ and $\mathrm{F}+\mathrm{L} 1$ hens, and 
Table 5. Effect of leptin on blood plasma LH, progesterone and oestradiol concentrations in fasted and re-fed hens (Expts 1 and 2)

\begin{tabular}{|c|c|c|c|c|c|c|}
\hline \multirow[b]{2}{*}{ Hormone tested } & \multirow[b]{2}{*}{ Treatment* } & \multicolumn{5}{|c|}{ Day of the experiment ${ }^{\dagger}$} \\
\hline & & 0 & 3 & 6 & 11 & $14-17^{\ddagger}$ \\
\hline \multirow[t]{4}{*}{$\mathrm{LH}\left(\mathrm{ng} \mathrm{ml} \mathrm{l}^{-1}\right)$} & Control & $4.20 \pm 0.22^{\mathrm{a}}$ & $3.81 \pm 0.19^{\mathrm{a}}$ & $4.16 \pm 0.18^{\mathrm{a}}$ & $3.61 \pm 0.39^{a}$ & $3.81 \pm 0.35^{\mathrm{a}}$ \\
\hline & $\mathrm{F}$ & $3.96 \pm 0.15^{\mathrm{a}}$ & $1.18 \pm 0.07^{\mathrm{c}}$ & $1.23 \pm 0.07^{b}$ & $2.34 \pm 0.23^{b}$ & $4.15 \pm 0.28^{\mathrm{a}}$ \\
\hline & $F+L 1-5$ & $3.72 \pm 0.16^{\mathrm{a}}$ & $1.98 \pm 0.13^{b}$ & $1.14 \pm 0.10^{b}$ & $3.14 \pm 0.27^{\mathrm{a}}$ & $4.35 \pm 0.45^{\mathrm{a}}$ \\
\hline & $\mathrm{F}+\mathrm{L} 1-10$ & $3.83 \pm 0.13^{\mathrm{a}}$ & $1.75 \pm 0.11^{b}$ & $1.23 \pm 0.14^{b}$ & $3.24 \pm 0.24^{\mathrm{a}}$ & NT \\
\hline \multirow[t]{4}{*}{ Progesterone (pg ml $\left.{ }^{-1}\right)$} & Control & $823.0 \pm 35.0^{\mathrm{a}}$ & $828.0 \pm 38.0^{\mathrm{a}}$ & $802.0 \pm 37.0^{\mathrm{a}}$ & $794.0 \pm 56.0^{\mathrm{a}}$ & $844.0 \pm 91.0^{\mathrm{a}}$ \\
\hline & $\mathrm{F}$ & $813.0 \pm 29.0^{\mathrm{a}}$ & $119.0 \pm 10.0^{b}$ & $175.0 \pm 18.0^{b}$ & $391.0+43.0^{b}$ & $1130.0 \pm 171.0^{\mathrm{a}}$ \\
\hline & $\mathrm{F}+\mathrm{L} 1-5$ & $825.0 \pm 38.0^{\mathrm{a}}$ & $114.0 \pm 10.0^{b}$ & $105.0 \pm 10.0^{c}$ & $325.0 \pm 30.0^{b, c}$ & $1201.0 \pm 193.0^{\mathrm{a}}$ \\
\hline & $\mathrm{F}+\mathrm{L} 1-10$ & $783.0 \pm 45.0^{\mathrm{a}}$ & $94.0 \pm 10.0^{b}$ & $103.0 \pm 14.0^{c}$ & $202.0 \pm 21.0^{c}$ & NT \\
\hline \multirow[t]{4}{*}{ Oestradiol $\left(\mathrm{pg} \mathrm{ml} \mathrm{m}^{-1}\right)$} & Control & $168.0 \pm 4.9^{a}$ & $164.0 \pm 6.1^{\mathrm{a}}$ & $159.0 \pm 6.6^{\mathrm{a}}$ & $149.0 \pm 13.8^{\mathrm{b}}$ & $151.0 \pm 11.1^{\mathrm{b}}$ \\
\hline & $\mathrm{F}$ & $156.0 \pm 10.5^{\mathrm{a}}$ & $10.0 \pm 1.8^{\mathrm{c}}$ & $17.0 \pm 2.3^{c}$ & $185.0 \pm 17.3^{b}$ & $167.0 \pm 10.8^{b}$ \\
\hline & $\mathrm{F}+\mathrm{L} 1-5$ & $161.0 \pm 7.2^{\mathrm{a}}$ & $28.0 \pm 2.4^{b}$ & $42.0 \pm 3.3^{b}$ & $288.0 \pm 15.8^{\mathrm{a}}$ & $217.0 \pm 17.8^{\mathrm{a}}$ \\
\hline & $\mathrm{F}+\mathrm{L} 1-10$ & $155.0 \pm 18.1^{\mathrm{a}}$ & $23.0 \pm 3.3^{b}$ & $36.0 \pm 2.1^{b}$ & $200.0 \pm 13.7^{b}$ & NT \\
\hline
\end{tabular}

*All hens except the control were fasted from days 1 to 5 and then fed ad libitum; F + L1-5 hens received leptin $\left(250 \mu \mathrm{g} \mathrm{kg}{ }^{-1}\right.$ body weight, i.p., twice a day) for 5 days during fasting, whereas $\mathrm{F}+\mathrm{L} 1-10$ hens received leptin for 10 days during fasting and re-feeding (days 1-10); control and $\mathrm{F}$ hens received placebo (PBS-BSA).

†The data from Expts 1 and 2 for days 0,3 and 6 were first analysed by three-way ANOVA (treatment $\times$ day $\times$ experiment). As the $F$ values of the interaction effects (treatment $\times$ experiment and day $\times$ experiment) were not significant $(P<0.78$ and $P<0.64$, respectively) the results of both experiments were pooled. However, as the $F$ value of the interaction effect (treatment $\times$ day) was highly significant $(P<0.001)$ the results for each day were re-analysed by one-way ANOVA followed by Tukey's Studentized Range (HSD) test. Each value is the mean \pm SEM from 12 to 48 hens. The values for days 0, 3 and 6 are the means from Expts 1 and 2; the values for day 11 are from Expt 2; and the values for days 14-17 are from Expt 1. Means marked with the same superscript letters in the same column do not differ significantly $(P<0.05)$.

${ }^{\ddagger}$ Resumption of egg laying. NT: not tested.

attenuated the stimulatory effect of leptin given during fasting on ovarian oestradiol content $(P<0.05)$.

\section{Expression of leptin receptors $m R N A$}

RT-PCR performed with two different pairs of primers located in the sequence encoding the extracellular domain (rec1) and the cytoplasmatic domain (rec2) of the receptor demonstrated that the long form of leptin receptor mRNA was expressed in all examined tissues of control laying hens (Fig. 3). The receptor mRNA expression was highest in the hypothalamus, lower in the hypophysis, and lowest in the ovary. Relatively high expression of leptin receptor mRNA was found in stroma with follicles $<1 \mathrm{~mm}$ and in the wall of white $(1-8 \mathrm{~mm})$ and small yellow (>8-12) follicles. High expression was also detected in the granulosa layer of yellow preovulatory F3 follicles, whereas leptin receptor was expressed but hardly detectable in the granulosa layer of F2 and F1 follicles. In contrast, higher expression of leptin receptor in the theca layer was maintained in all maturing yellow preovulatory F3-F1 follicles.

\section{Discussion}

The purpose of the present study was to evaluate whether leptin is involved in the regulation of chicken ovarian function in fasted hens. The study used externally injected recombinant chicken leptin prepared according to the published cDNA sequence (Taouis et al., 1998; Ashwell et al., 1999a). The present results clearly indicate that recombinant chicken leptin, given during fasting, delays the negative effects of fasting on egg production by slowing the onset of ovarian cell apoptosis and follicular regression. This finding is in agreement with, and extends, an earlier report of the effects of ovine leptin in fasted chickens (Paczoska-Eliasiewicz et al., 2001). Hens treated with leptin during fasting also returned to egg production more quickly than hens fasted without leptin treatment.

Unlike in mammals, the progesterone in chicken ovary is synthesized mainly by the granulosa cells, whereas oestradiol is synthesized by the theca cells (Huang et al., 1979; Bahr et al., 1983; Etches and Duke, 1984; Lee and Bahr, 1994). The steroidogenic activity of the granulosa and the theca layers changes during follicular development. In white non-hierarchical follicles the granulosa layer is steroidogenically incompetent. The theca layer is steroidogenically active both in white non-hierarchical and yellow hierarchical follicles (Davidson et al., 1979; Nitta et al., 1991; Tilly et al., 1991). Measurement of progesterone and oestradiol concentrations showed that fasting markedly decreased the ovarian content of these steroids as well as their blood plasma concentrations, confirming previous observations (Proszkowiec and Rząsa, 2001). Plasma LH concentrations were also considerably decreased in agreement with other studies (Tanabe et al., 1981; 


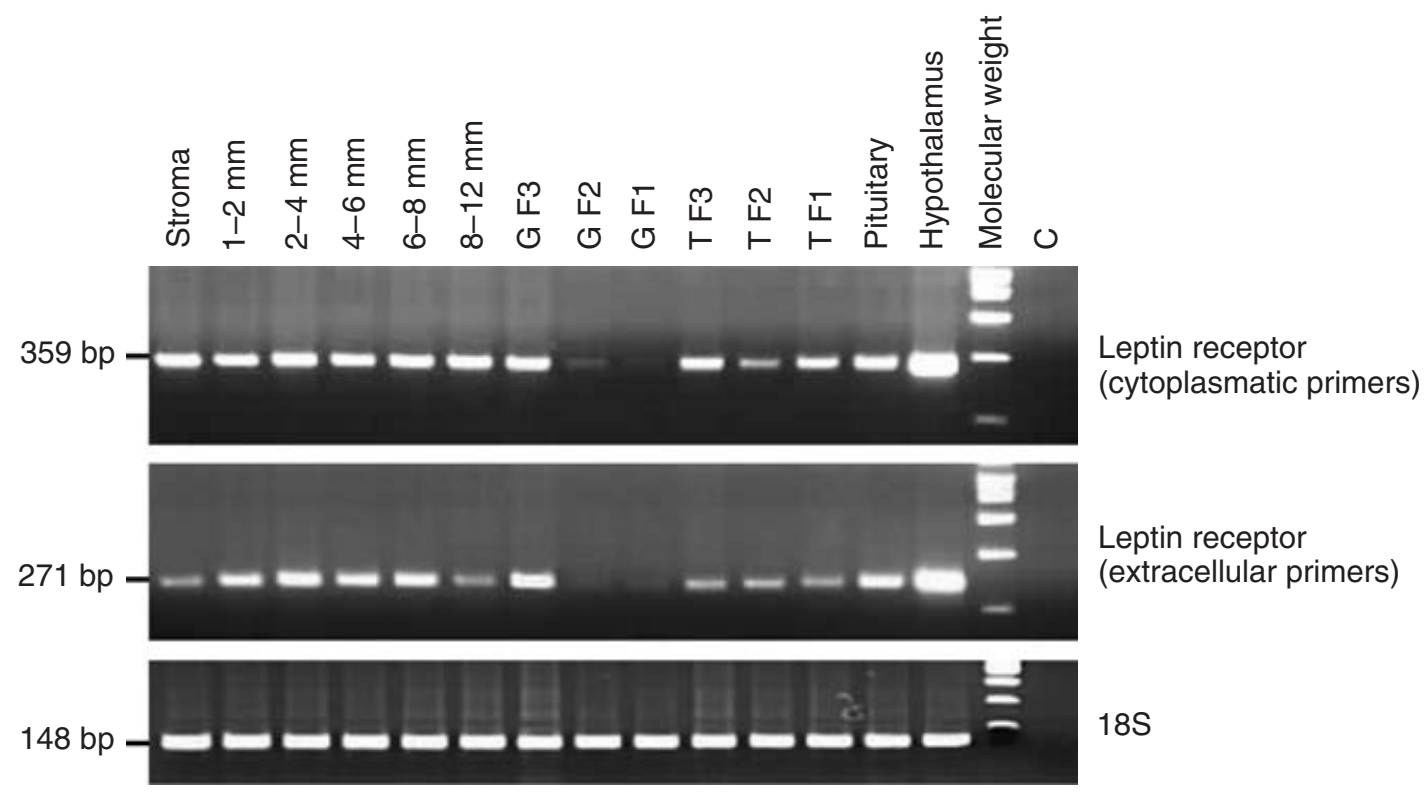

Fig. 3. Expression of leptin receptor in the ovary, the hypohysis and the hypothalamus of laying hens. RT-PCR amplified fragments of leptin receptor and 18S ribosomal RNA were separated by gel electrophoresis (1.5\%) and produced a 359, 271 and $148 \mathrm{bp}$ fragment of the cytoplasmatic and the extracellular domain of leptin receptor, and of $18 \mathrm{~S}$ RNA, respectively. The lengths of fragments were as expected. Expression of leptin receptor was examined within the ovary in stroma with cortical follicles $<1 \mathrm{~mm}$, the wall of white $(1-8 \mathrm{~mm})$ and small yellow $(>8-12 \mathrm{~mm}$ ) follicles and the granulosa $(\mathrm{G})$ and the theca $(\mathrm{T})$ layer of the three largest yellow hierarchical F3-F1 follicles (F3 $<\mathrm{F} 2<\mathrm{F} 1 ; 25-35 \mathrm{~mm}$ ). Water was used as control (C).

Etches et al., 1984; Hoshino et al., 1988). However, the present results show, for the first time, that leptin attenuates this decrease. After 2 days of fasting, leptintreated fasted hens had slightly but significantly higher plasma LH and oestradiol concentrations than did hens fasted without leptin injections. Ovarian progesterone and oestradiol content was considerably $(1.7$-fold and 1.9-fold, respectively) increased in comparison with that of fasted hens. After 5 days of fasting with leptin treatment, ovarian progesterone content was 2.5 -fold and oestradiol content was 1.7-fold higher than in fasted hens, whereas plasma LH decreased to the concentration observed in fasted hens. In chicken ovary, progesterone is produced by the granulosa cells of yellow hierarchical follicles under the stimulatory control of $\mathrm{LH}$, whereas oestradiol is produced by the stromal tissue and the theca cells of white and yellow follicles (for review, see Johnson, 1996). The fall in plasma $\mathrm{LH}$, progesterone and oestradiol concentrations during fasting is the result of reduced pituitary response to $\mathrm{LH}$ releasing hormone (Tanabe et al., 1981; Kawashima et al., 1992). However, the present results indicate that the effect of exogenous leptin on ovarian steroidogensis cannot be explained only by its stimulatory action at the central level as higher ovarian progesterone and oestradiol concentrations were observed in leptin-treated hens after 5 days of fasting without any difference in LH concentrations. Decuypere et al. (1992) showed that the rapid fall in progesterone synthesis by yellow hierarchical follicles after feed withdrawal is not due to a reduced follicular sensitivity but solely due to a decrease in stimulatory factor(s), as during the first few days of fasting granulosa cells exhibit an increased responsiveness to $\mathrm{LH}$ in vitro and in vivo. Therefore, it seems that leptin given during fasting exerted its stimulatory action both at the central and the peripheral level. After 5 days of re-feeding (day 11) the stimulatory effect of leptin given during fasting on oestradiol synthesis in the ovary was the most pronounced and could not be attributed to the influence of re-feeding only as plasma LH concentrations were significantly lower in fasted hens than in leptintreated hens. After restoration of egg laying, higher concentrations of plasma oestradiol were still maintained in hens that received leptin during fasting. Oestradiol is essential during egg production for synthesis of egg yolk and mobilization of calcium for egg shell formation (for review, see Harvey et al., 1987). The main sources of ovarian oestradiol are small white follicles and ovarian stroma with numerous cortical follicles containing more than $50 \%$ of ovarian aromatase activity (Armstrong, 1984) and producing more than $>80 \%$ of ovarian oestradiol (Senior and Furr, 1975). Thus, the effect of leptin given during fasting in stimulating oestradiol production during re-feeding might be responsible for the accelerated return to egg production observed in leptintreated hens.

One of the most surprising results of the present study was the finding that continuation of leptin treatment 
into the re-feeding period (group F + L1-10) considerably delayed the restoration of the ovary by attenuating the entry of white follicles into the hierarchy of yellow preovulatory follicles and by suppressing the growth of yellow follicles as evidenced by a 3.7-fold lower number and 10.8-fold lower mass of normal yellow follicles in the ovary after re-feeding. This slow growth of yellow hierarchical follicles resulted in lower ovarian progesterone content and lower plasma progesterone concentration as progesterone synthesis occurs primarily in the largest yellow follicles (Johnson, 1996). Plasma $\mathrm{LH}$ concentrations returned to normal after re-feeding in this group, indicating that the observed delay in the restoration of the hierarchy of yellow preovulatory follicles was not due to lack of LH stimulation. Two possible reasons for these findings should be considered: (i) prolongation of leptin injections caused the decrease in food intake and the limited amount of metabolites might partially account for attenuating the normal ovarian growth; and (ii) resulting hyperleptinaemia saturated all leptin receptors in the blood-brain barrier leading to the maximal central effect of leptin, and in parallel, the excess of peripheral leptin exerted a direct inhibitory effect on the ovary leading to suppression of follicle selection and differentiation.

The presence of leptin receptor mRNA in laying chickens has been shown in the hypothalamus (Horev et al., 2000) and non-compartmented ovary (Okhubo et al., 2001). In the present study, expression of leptin receptor mRNA was found in the hypothalamus, the hypophysis and all examined compartments of the ovary. The presence of leptin receptor in different compartments of the laying hen ovary and changes in its expression during follicular growth and maturation substantiates the notion that the effect of leptin on ovarian function may result not only from indirect central activity but also from a direct peripheral action.

As in mammals, follicular atresia in birds is mediated via apoptosis and initiated within the granulosa layer (for review, see Johnson, 2002). To answer the question whether suppression of follicular atresia observed in hens treated with leptin during fasting might be a result of the anti-apoptotic action of leptin, the wall of the three largest hierarchical follicles was examined for apoptotic changes by the TUNEL method. Fastinginduced increase in the number of apoptotic cells on day 3 was completely attenuated by leptin. Partial attenuation was also observed on day 6 , clearly indicating the anti-apoptotic effect of the hormone. The anti-apoptotic action of leptin in rat ovary related to the accelerated onset of puberty has been recently reported (Almog et al., 2001) and similar results were also obtained in immature chickens (Paczoska-Eliasiewicz et al., 2003a,b). Furthermore, recent studies in mammals have shown that progesterone acting via nuclear receptor inhibits apoptosis in periovulatory follicles (for review, see Markström et al., 2002). The possibility that in birds progesterone may also act as a follicular survival factor by forming a complex with its nuclear receptor in the granulosa cells (Yoshimura and Bahr, 1991) should be taken into consideration, as leptin given during fasting significantly increased progesterone synthesis by the granulosa layer and this hormone was not released into circulation but accumulated in the follicles.

In conclusion, the present results clearly demonstrate that leptin treatment ameliorates the negative effects of fasting on ovarian function by attenuating follicular apoptosis and indicate that leptin might be involved in the adaptation to starvation as its blood plasma concentration is lower in fasted than in fed state (Dridi et al., 2000b). The mechanism of the observed leptinmediated anti-apoptotic effect in the chicken ovary is yet unclear and further experiments to clarify this point are in progress. Furthermore, the present study has shown that recombinant leptin prepared according to the published cDNA sequence (Taouis et al., 1998; Ashwell et al., 1999a) has the potential to serve as a tool for regulating physiological events related to egg production.

The authors thank H. Foot from the Department of Agricultural Economics at the Hebrew University (Rehovot, Israel) for the help in statistical analyses. This study was supported by grant no. 6P06D 01020 from Polish State Committee for Scientific Research (KBN) to H. E. Paczoska-Eliasiewicz, and by grant no. 594/02 from the Israeli Science Foundation (ISF) to A. Gertler.

\section{References}

Ahima RS, Prabakaran D, Mantzoros C, Qu D, Lowell BB, Maratos-Flier E and Flier JS (1996) Role of leptin in the neuroendocrine response to fasting Nature 382 250-252

Ahima RS, Dushay J, Flier SN, Prabakaran D and Flier JS (1997) Leptin accelerates the onset of puberty in normal female mice Journal of Clinical Investigations 99 391-395

Ahima RS and Flier JS (2000) Leptin Annual Review of Physiology 62 413-437

Almog B, Gold R, Tajima K et al. (2001) Leptin attenuates follicular apoptosis and accelerates the onset of puberty in immature rats Molecular and Cellular Endocrinology 183 179-191

Armstrong DG (1984) Ovarian aromatase activity in the domestic fowl (Gallus domesticus) Journal of Endocrinology 100 81-86

Ashwell C, Czerwinski SM, Brocht DM and McMurtry JP (1999a) Hormonal regulation of leptin expression in broiler chickens American Journal of Physiology 276 R226-R232

Ashwell CM, McMurtry JP, Wang X-H, Zhou $\mathrm{Y}$ and Vasilatos-Younken $\mathbf{R}$ (1999b) Effects of growth hormone and pair-feeding on leptin mRNA expression in liver and adipose tissue Domestic Animal Endocrinology $1777-84$

Bahr JM, Wang S-C, Huang MY and Calvo F (1983) Steroid concentrations in isolated theca and granulosa layers of preovulatory follicles during the ovulatory cycle of the domestic hen Biology of Reproduction 29 $326-334$

Brake J (1993) Recent advances in induced molting Poultry Science 72 929-931

Bungo T, Shimojo M, Masuda Y, Tachibanab T, Tanaka S, Sugahara $K$ and Furuse M (1999) Intracerebroventricular administration of mouse leptin does not reduce food intake in chickens Brain Research 817 196-198

Caprio M, Fabbrini E, Isidori AM, Aversa A and Fabbri A (2001) Leptin in reproduction Trends in Endocrinology and Metabolism 12 65-72 
Chehab FF, Lim ME and Lu R (1996) Correction of the sterility defect in homozygotous obese female mice by treatment with the human recombinant leptin Nature Genetics 12 318-320

Chehab FF, Mounzih KM, Lu R and Lim ME (1997) Early onset of reproductive function in normal female mice treated with leptin Science 275 88-90

Cheung CC, Thornton JE, Kuijper JL, Weigle DS, Clifton DK and Steiner RA (1997) Leptin is a metabolic gate for the onset of puberty in the female rat Endocrinology 138 855-858

Cheung CC, Thornton JE, Nyrani SD, Clifton DK and Steiner RA (2001) A reassessment of leptin role in triggering the onset of puberty in the rat and mouse Neuroendocrinology 74 12-21

Chowdhury VS and Yoshimura Y (2002) Cell proliferation and apoptosis in the anterior pituitary of chicken during inhibition and resumption of laying General and Comparative Endocrinology 125 132-141

Clarke IJ and Henry BA (1999) Leptin and reproduction Reviews of Reproduction 4 48-55

Davidson MF, Gilbert AB and Wells JW (1979) Activity of ovarian $\Delta^{5}-3 \beta$ hydroxysteroid dehydrogenase in the domestic fowl (Gallus domesticus) with respect to age Journal of Reproduction and Fertility 57 61-64

Decuypere E, Feng PY, Verheyen G and Vanmontfort D (1992) Induced stop of egg laying results in a transient LH-sensitivity of the progesterone producing cells both in vitro and in vivo. Ornis Scandinavica 23 340-345

Denbow DM, Meade S, Robertson A, McMurtry JP, Richards $M$ and Ashwell CM (2000) Leptin-induced decrease in food intake in chickens Physiology and Behavior 69 359-362

Dridi S, Raver N, Gussakovsky EE, Derouet M, Picard M, Gertler A and Taouis M (2000a) Biological activities of recombinant chicken leptin C4S analog compared with unmodified leptins American Journal of Physiology, Endocrinology and Metabolism 279 E116-E123

Dridi S, Williams J, Bruggeman V, Onagbesan M, Raver N, Decuypere E, Djiane J, Gertler A and Taouis M (2000b) A chicken leptin-specific radioimmunoassay Domestic Animal Endocrinology 18 325-335

Doyon C, Drouin G, Trudeau VL and Moon TW (2001) Molecular evolution of leptin General and Comparative Endocrinology 124 188-198

Duggal PS, Van Der Hoek KH, Milner CR, Ryan NK, Armstrong DT, Magoffin A and Norman R (2000) The in vivo and in vitro effects of exogenous leptin on ovulation in the rat Endocrinology 141 1971-1976

Dunn IC, Girishvarma G, Talbot RT, Waddington D, Boswell T and Sharp PJ (2001) Evidence for low homology between the chicken and mammalian leptins In Avian Endocrinology pp 327-336 Eds A Davidson and CM Chaturvedi. Norosa Publishing House, New Delhi

Etches RJ and Duke CE (1984) Progesterone, androstendione and oestradiol content of theca and granulosa tissue of the four largest ovarian follicles during the ovulatory cycle of the domestic hen (Gallus domesticus) Journal of Endocrinology 103 71-76

Etches RJ, Williams JB and Rząsa J (1984) Effects of corticosterone and dietary changes in the hen ovarian function, plasma $\mathrm{LH}$, and steroids and the response to exogenous LH-RH Journal of Reproduction and Fertility 70 121-130

Flier JS (1998) What's in a name? In search of leptin's physiologic role Journal of Clinical Endocrinology and Metabolism 83 1407-1413

Friedman JM and Halaas JL (1998) Leptin and the regulation of body weight in mammals Nature $395763-779$

Friedman-Einat M, Boswell T, Horev G, Girishvarma G, Dunn IC, Talbot RT and Sharp PJ (1999) The chicken leptin gene: has it been cloned? General and Comparative Endocrinology 115 354-363

Gavrieli Y, Sherman Y and Ben-Sasson SA (1992) Identification of programmed cell death in situ via specific labeling of nuclear DNA fragmentation Journal of Cell Biology 119 493-501

Gilbert AB, Evans AJ, Perry MM and Davidson MH (1977) A method for separating the granulosa cells, the basal lamina and theca of the preovulatory ovarian follicle of the domestic fowl (Gallus domecticus) Journal of Reproduction and Fertility 50 179-181

Gilbert AB, Perry MM, Walker MA and Waddington D (1985) Identification of atresia in small ovarian follicles of the domestic hen (Gallus domesticus) IRCS Medical Science 13 732-733

Harvey S, Scanes CG and Philips JG (1987) Avian reproduction. In Fundamentals of Comparative Vertebrate Endocrinology pp 125-185
Eds J Chester-Jones, PM Ingleton and JG Phillips. Plenum Press, New York and London

Heryanto B, Yoshimura Y and Tamura T (1997a) Cell proliferation in the process of oviductal tissue remodeling during induced molting in hens Poultry Science 76 1580-1586

Heryanto B, Yoshimura Y, Tamura T and Okamoto T (1997b) Involvement of apoptosis and lysosomal hydrolase activity in the oviductal regression during induced molting in chickens: a cytochemical study for end labeling of fragmentated DNA and acid phosphatase Poultry Science 76 67-72

Horev G, Einat P, Aharoni T, Eshdat $\mathbf{Y}$ and Friedman-Einat M (2000) Molecular cloning and properties of the chicken leptin-receptor (CLEPR) gene Molecular and Cellular Endocrinology 162 95-106

Hoshino S, Suzuki M, Kakegawa T, Imai K, Wakita M. , Kobayashi Y and Yamada Y (1988) Changes in plasma thyroid hormones, luteinizing hormone (LH), estradiol, progesterone and corticosterone of laying hens during a forced molt Comparative Biochemistry and Physiology 90A 355-359

Houseknecht KL, Baile CA, Matteri RL and Spurlock ME (1998) The biology of leptin: a review Journal of Animal Science 76 1405-1420

Huang ES-R, Kao KJ and Nalbandov AV (1979) Synthesis of sex steroids by cellular components of chicken follicles Biology of Reproduction 20 454-461

Ingvartsen KL and Boisclair YR (2001) Leptin and the regulation of food intake, energy homeostasis and immunity with special focus on periparturient ruminants Domestic Animal Endocrinology 21 215-250

Johnson AL (1996) The avian ovarian hierarchy: a balance between follicle differentiation and atresia Poultry and Avian Biology Reviews 7 99-110

Johnson AL (2002) Granulosa cell apoptosis: conservation of cell signaling in an avian ovarian model system Biological Signals and Receptors 9 96-101

Kawashima M, Takeo M, Kamiyoshi M and Tanaka K (1992) Luteinizing hormone-releasing hormone receptor bindings of the hen pituitary: difference between laying and molting hens, effects of ovarian steroid hormones in vitro, and changes during an ovulatory cycle Poultry Science 71 1079-1086

Krishnan KA, Proudman JA and Bahr JM (1994) Purification and partial characterization of isoforms of luteinizing hormone from the chicken pituitary gland Comparative Biochemistry, Physiology and Biochemical Molecular Biology 108 253-264

Lee KA and Bahr JM (1994) Utilization of substrates for testosterone and estradiol-17 $\beta$ production by small follicles of the chicken ovary Domestic Animal Endocrinology 11 307-314

Markström E, Svensson ECh, Shao R, Svanberg B and Billing H (2002) Survival factors regulating ovarian apoptosis dependence on follicle differentiation Reproduction 123 23-30

Moschos S, Chan JL and Mantzoros CS (2002) Leptin and reproduction: a review Fertility and Sterility 77 433-434

Nagatani S, Guthikonda P, Thompson RC, Tsukamura H, Maeda K-I and Foster DL (1988) Evidence for GnRH regulation by leptin: leptin administration prevents reduced pulsatile $\mathrm{LH}$ secretion during fasting Neuroendocrinology 67 370-376

Nagatani S, Zeng Y, Keisler DH, Foster DL and Jaffe CA (2000) Leptin regulates pulsatile luteinizing hormone and growth hormone secretion in the sheep Endocrinology 141 3965-3975

Nitta H, Osawa Y and Bahr JM (1991) Immunolocalization of steroidogenic cells in small follicles of the chicken ovary: anatomical arrangement and location of steroidogenic cells change during follicular development Domestic Animal Endocrinology 8 587-594

Ohkubo T, Tanaka M and Nakashima K (2000) Structure and tissue distribution of chicken leptin receptor (cOb-R) mRNA Biochimica Biophysica Acta 1491 303-308

Paczoska-Eliasiewicz H, Rząsa J, Proszkowiec M, Hrabia A, Sechman A, Rozenboim I and Gertler A (2001) Leptin affects ovarian activity in fasted hens (Gallus domesticus) 10th International Symposium of Polish Network of Molecular and Cellular Biology UNESCO/PAS Molecular and Physiological Aspects of Regulatory Processes of the Organism' (Cracow) pp 277-278 Ed. H Lach 
Paczoska-Eliasiewicz HE, Proszkowiec M, Rząsa J and Gertler A (2003a) Anti-apoptotic activity of leptin in chicken ovary Proceedings of Apoptosis 2003: from signaling pathways to therapeutical tools (Luxemburg) p 233 Ed M. Dietrich

Paczoska-Eliasiewicz HE, Proszkowiec M, Rząsa J, Jacek T, Sechman A, Mika M, Proudman J, Cassy S and Gertler A (2003b) Leptin-enhanced onset of sexual maturity in chickens is correlated with its anti-apoptotic activity in the ovary The Endocrine Society 85th Annual Meeting (Philadelphia) Abstract no. OR3-1

Pitel F, Monbrun C, Gellin J and Vignal A (2000) The chicken LEP (OB) gene has not been mapped Animal Genetics 31281

Prentice AM, Moore SE, Collinson AC and O'Connell MA (2002) Leptin and undernutrition Nutrition Reviews 60 S56-S67

Proszkowiec M and Rząsa J (2001) Variation in the ovarian and plasma progesterone and estradiol levels of the domestic hen during pause in laying Folia biologica (Kraków) 49 285-289

Raver N, Taouis M, Dridi S, Derouet M, Simon J, Robinzon B, Dijane J and Gertler A (1998) Large-scale preparation of biologically active recombinant chicken obese protein (leptin) Protein Expression and Purification 14 403-408

Raver N, Gussakovsky EE, Keisler DH, Krishna R, Mistry J and Gertler A (2000) Preparation of recombinant bovine, porcine, and porcine W4R/R5K leptins and comparison of their activity and immunoreactivity with ovine, chicken, and human leptins Protein Expression and Purification 19 30-40

Raver N, Sandowski Y, Sakal E, Shohat S, Livnah O, Einat M and Gertler A (2003) Recombinant human and chicken leptin binding domains from respective leptin receptors Experimental Biology Annual Meeting San Diego, California, Abstract no. 1209

Richards MP, Caperna TJ, Elssaser TH, Ashwell CM and McMurtry JP (2000) Design and application of a polyclonal peptide antiserum for the universal detection of leptin protein Journal of Biochemical and Biophysical Methods 45 147-156

Saadoun A and Leclercq B (1983) Comparison of in vivo fatty acid synthesis of the genetically lean and fat chickens Comparative Biochemistry and Physiology B 75 641-644
Senior BE and Furr BJA (1975) A preliminary assessment of the source of oestrogen within the ovary of the domestic fowl (Gallus domesticus) Journal of Reproduction and Fertility 43 241-247

Smith GD, Jackson LM and Foster DL (2002) Leptin regulation of reproductive function and fertility Theriogenology 57 73-86

Tanabe Y, Ogawa T and Nakamura T (1981) The effect of short-term starvation on pituitary and plasma $\mathrm{LH}$, plasma estradiol and progesterone, and on pituitary response to $\mathrm{LH}-\mathrm{RH}$ in the laying hen (Gallus domesticus) General and Comparative Endocrinology 43 392-398

Taouis M, Chen JW, Daviaud C, Dupont J, Derouet M and Simon J (1998) Cloning the chicken leptin gene Gene 208 239-242

Taouis M, Dridi S, Cassy S, Benomar Y, Raver N, Rideau N, Picard M, Williams J and Gertler A (2001) Chicken leptin: properties and actions Domestic Animal Endocrinology 21 319-327

Tilly JL, Kowalski KI and Johnson AL (1991) Stage of ovarian follicular development associated with the initiation of steroidogenic competence in avian granulosa cells Biology of Reproduction 44 305-314

van Tuinen M, Sibley CG and Hedges SB (2000) The early history of modern birds inferred from DNA sequences of nuclear and mitochondrial ribosomal genes Molecular Biology and Evolution 17 451-457

Wolford JH (1984) Induced molting in laying fowls World's Poultry Science Journal 40 66-73

Yoshimura Y and Bahr JM (1991) Localization of progesterone receptors in pre-and postovulatory follicles of the domestic hen Endocrinology 128 323-330

Yoshimura Y, Heryanto B and Tamura T (1997) Changes in the population of proliferating cells in chicken anterior pituitary during induced molting: an immunocytochemical analysis for proliferating cell nuclear antigen Poultry Science 76 1569-1573

Received 30 April 2003

First decision 11 July 2003

Revised manuscript received 22 August 2003.

Accepted 2 September 2003. 